\title{
Antimicrobial Peptide Resistance Mechanisms of Human Bacterial Pathogens
}

\author{
Victor Nizet \\ Department of Pediatrics, Division of Infectious Diseases, \\ University of California, San Diego, 9500 Gilman Drive, \\ MC 0687, La Jolla, CA 92093-0687
}

\begin{abstract}
The critical role played by antimicrobial peptides (AMPs) in mammalian innate immunity is increasingly recognized. Bacteria differ in their intrinsic susceptibility to AMPs, and the relative resistance of some important human pathogens to these defense molecules is now appreciated as an important virulence phenotype. Experimental analysis has identified diverse mechanisms of bacterial AMP resistance including altered cell surface charge, active efflux, production of proteases or trapping proteins, and modification of host cellular processes. The contribution of these resistance mechanisms to pathogenesis is confirmed through direct comparison of wild-type bacteria and AMP-sensitive mutants using in vivo infection models. Knowledge of the molecular basis of bacterial AMP resistance may provide new targets for antimicrobial therapy of human infectious diseases.
\end{abstract}

\section{Introduction}

In a complex environment, higher organisms face the constant threat of microbial infection. An important component of mammalian innate immunity is recognized to be the production of small, cationic antimicrobial peptides (AMPs). Recent discoveries using knockout mice and transgenic expression systems have confirmed that AMPs play a crucial role in restricting microbial proliferation to skin and mucosal surfaces, and preventing spread to the deep tissues where serious infection may develop. Studies of human AMP expression have revealed sophisticated systems of regulation: skin keratinocytes and mucosal epithelial cells produce very low levels of AMP under baseline conditions, but their expression of AMPs can be induced dramatically in response to injury or infectious stimuli. These epithelial barrier functions are further supplemented by AMPs produced by leukocytes resident in the tissues (macrophages, dendritic cells, mast cells) or recruited in the acute inflammatory response (neutrophils).

Throughout evolution, each member of the human microflora seeks to maintain a survival advantage. Microbial adaptation is appreciated to come more quickly, with replication times often measured in minutes and hours rather than decades between human generations. As is increasingly the case with pharmaceutical antibiotics, it appears that bacteria exposed to human AMPs have evolved under selective pressure to develop

For correspondence: vnizet@ucsd.edu mechanisms of resistance. However, even though these selective pressures have existed for countless centuries, human AMPs still possess a broad-spectrum of potent activity against a diverse array of Gram-positive and Gram-negative bacterial species, fungi, as well as certain protozoan parasites and enveloped viruses. Though the ability to resist AMP killing appears to be a formidable challenge for microbial evolution, AMP resistance is increasingly recognized as a discriminating feature of some important human pathogens. When AMPs are rendered ineffective as a component of barrier defense or phagocytic killing, remaining host microbicidal functions maybe insufficient to prevent the risk of invasive infections produced by the AMP-resistant organism.

Here we review our current understanding of mechanisms that human pathogens have evolved to resist AMP killing. In particular, research studies on bacterial disease agents have uncovered a great diversity of viable strategies for avoiding AMP killing. These include decreased affinity through cell surface alterations, external trapping mechanisms, membrane efflux pumps, peptidases, and downregulation of host AMP production. Experimental evidence linking the degree of bacterial AMP resistance to pathogenic potential will be discussed, as these findings corroborate the crucial role of AMP in host innate immune defense. Bacterial resistance to AMP has implications for a number of human disease conditions, and improved understanding of these mechanism may provide novel targets for antibiotic drug design.

\section{AMP resistance through cell surface modification}

The antibacterial action of the defensin and cathelicidin classes of human AMPs is derived from their unique amphipathic structure and charge characteristics. Not unlike individual tissue cells of higher organisms, the surface of microbes tends to display a preponderance of negative charge. The cationic nature of AMPs allows them to be drawn electrostatically to engage a microbe threatening to breech an epithelial barrier, or in the case of phagocytic cells, to effect the killing of a microbe following endocytotic uptake. When a critical concentration of AMPs accumulate on the microbial surface, intercolation and assembly of their hydrophobic faces within the cytoplasmic membrane leads to formation of ion channels or aqueous pores, leading to microbial death through hypoosmotic lysis (Gutsmann et al., 2001; Oren et al., 1999). Certain cathelicidins may additionally reach intracellular targets to disrupt microbial protein synthesis (Boman et al., 1993).

In bacteria, the principal site of AMP action is the cytoplasmic membrane. To reach this target, AMPs must negotiate and traverse enveloping structures of varying complexity. Gram-positive bacteria lack an outer membrane, but possess a thick cell wall composed of heavily crosslinked polymers of teichoic or lipoteichoic acids and peptidoglycan. Gram-negative bacteria do 
not produce teichoic acids, but have a multilayered surface structure including a peptidoglycan matrix in the periplasmic space beneath an outer membrane. This outer membrane contains the bound complex of lipid A, core polysaccharide and specific side-chain (O) polysaccharides known as lipopolysaccharide (LPS). Additional complexity to bacterial surfaces is generated by proteins anchored to the cell wall or membrane, and many human bacterial pathogens are notable for their production of surface polysaccharide capsules.

The Gram-positive human pathogen Staphylococcus aureus is a prominent cause of wound infections, cellulitis, abscesses, osteomyelitis, septic arthritis, endocarditis and septicemia. S. aureus exhibits significantly higher minimum inhibitory concentrations (MICs) to human AMPs than observed in similar organisms (Peschel and Collins, 2001). It appears that specific modifications of teichoic acid in the $S$. aureus cell wall go a long way to explaining this enhanced AMP resistance. Teichoic acids are polyol phosphate polymers, e.g. polyglycerol phosphate and polyribitol phosphate, forming a backbone that can be further modified by substitutions with amino sugars (e.g. $\mathrm{N}$-acetylglucosamine) or the amino acid D-alanine. Generally, teichoic acids are polyanionic because of the abundance of phosphate groups in the repeating structure. However, incorporation of D-alanine is accomplished by an ester bond that leaves the positively charged amino group free and exposed (Fig. 1).

$S$. aureus incorporates significant quantities of Dalanine into its teichoic acid, reducing cell wall negative charge, and serving to repel the cationic AMPs before they can reach their target of action (Peschel, 2002). D-alanylation of teichoic acid in the $S$. aureus cell wall is accomplished by the gene products of a four gene operon, ditABCD. S. aureus harboring mutations in the $d l t$ operon have increased cell-surface negative charge and are more sensitive to killing by human $\alpha$-defensins and cathelicidin as well as variety of other cationic AMPs (Kristian et al., 2003b; Peschel et al., 1999). Conversely, overexpression of the dlt genes in wild-type $S$. aureus by introducing additional copies of the operon on a plasmid led to increased D-alanylation of teichoic acid, decreased cell surface negative charge, and increased levels of AMP resistance (Peschel et al., 1999). These discoveries prompted analysis of dlt operons that are present in other Gram-positive bacterial pathogens of humans. Group B Streptococcus (GBS) and Listeria monocytogenes each produce septicemia and meningitis in human neonates and immunocompromised individuals. Mutation of the GBS dltA gene blocked D-alanylation of teichoic acid and increased the susceptibility of the organism to killing by human defensins and other mammalian AMPs

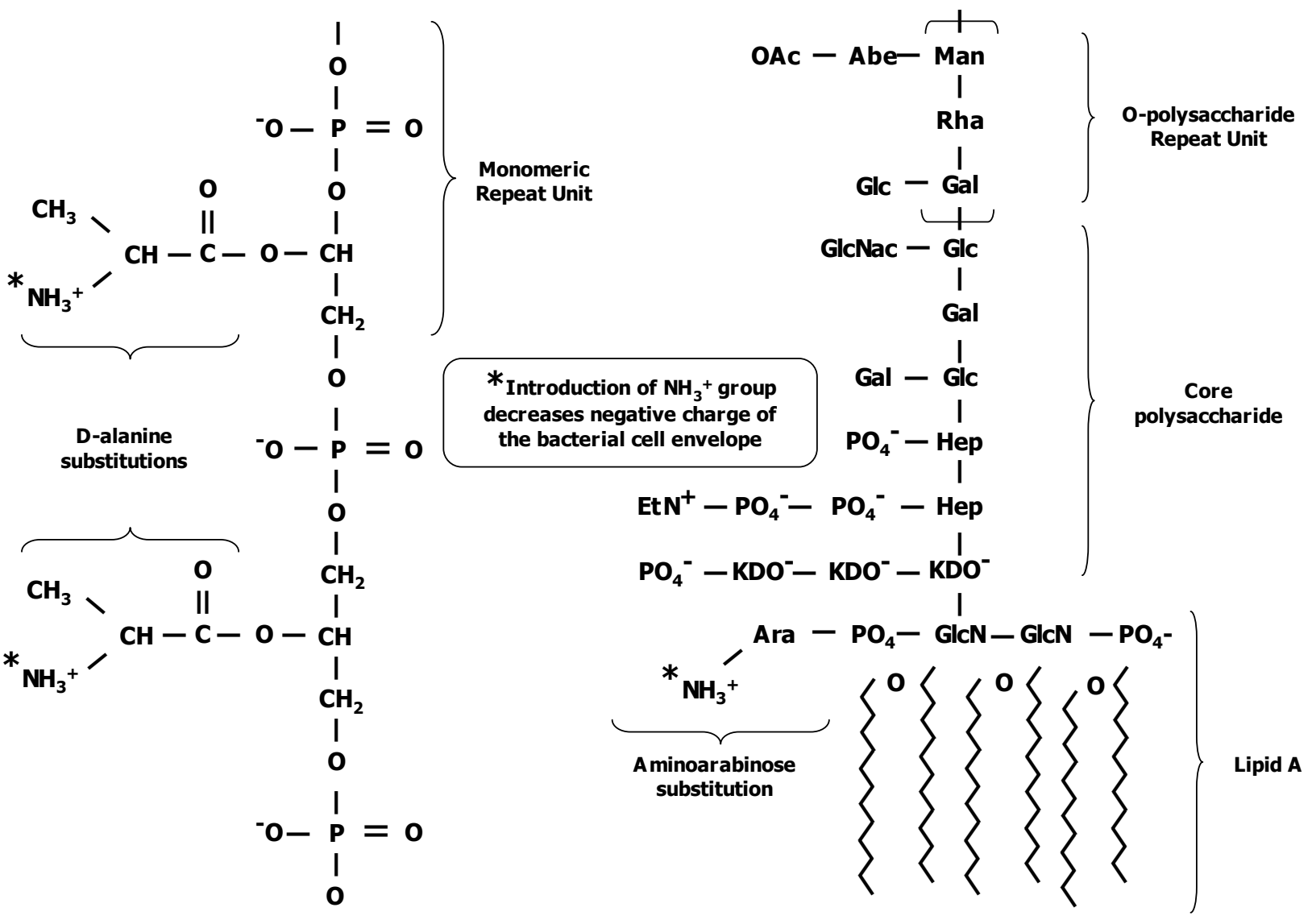

Teichoic Acid in Gram + Cell Wall

Lipopolysaccharide in Gram- Outer Membrane

Fig. 1. Some specific surface modifications associated with decreased negative charge and increased resistance to cationic antimicrobial peptides. 
(Poyart et al., 2003). Similarly, inactivation of dltA in $L$. monocytogenes, an intracellular pathogen, led to decreased interaction with phagocytic and nonphagocytic cells and increased susceptibility to cationic AMPs (Abachin et al., 2002). The Gram-positive rod Bacillus subtilis also uses ditA modification of techoic acid to reduce AMP sensitivity (Cao and Helmann, 2004).

Screening of an $S$. aureus mutant library for increased susceptibility to AMPs recently led to identification of another gene, $m p r F$, that encodes a novel function for modification of cell surface charge. The mprF mutant was more sensitive to killing by neutrophil defensins, and was found to lack a positively-charged membrane phospholipid derivative enriched in the amino acid L-lysine (Peschel et al., 2001). Absence of this unusual phospholipid leaves only the highly anionic phosphatidylglcerol and diphosphatidylglycerol components in the cell membrane resulting in a high attraction for cationic AMPs. Expression of the mprF gene in Escherichia coli was sufficient to confer production of the cationic lysine-substituted phosphatidylglcerol (L-PG), indicating that MprF indeed represents the L-PG synthase enzyme (Staubitz et al., 2004). Reduced lysyl-phosphatidylglycerol content in the cell membrane of $S$. aureus can also be seen with mutation of the lysC gene, which is involved in the biosynthesis of lysine from aspartic acid, with resulting sensitivity to human $\beta$-defensin and cathelicidin killing (Nishi et al., 2004).

In Gram-negative bacteria, the permeability and charge characteristics of the outer membrane influence the ability of cationic AMPs to reach their target on the cytoplasmic membrane. The outer leaflet of the outer membrane serves as the site of attachment for lipid $A$, an anionic dimer of glucosamine linked to fatty acid chains and flanked by polar phosphate groups. Covalently bonded to lipid $A$ is a core polysaccharide and specific side-chain "O" polysaccharides that vary from species to species (Fig. 1a). The lipid A-polysaccharide complex is referred to as lipopolysaccharide (LPS) or endotoxin because of its proinflammatory and toxic effects in animals including humans. Modifications of the lipid A component of LPS appear to reduce overall negative charge appear to represent an important mechanism of AMP resistance in several Gram-negative human pathogens.

Salmonella species produce gastroenteritis and systemic infections including enteric fever in humans. The relative resistance of Salmonella to AMP killing has been studied extensively in the model organism $S$. enterica serovar typhimurium. A prominent S. enterica modification conferring resistance is the addition of 4aminoarabinose (Ara4N) to the phosphate group of the lipid $A$ backbone, for which two genetic loci are required: pmrE and pmrHFIJKLM. Nonpolar mutagenesis studies have demonstrated that all genes except pmrM are essential for Ara4N addition to lipid A and AMP resistance. Expression of these genes can be upregulated 3,000-fold by the actions of a two-component regulator system, PmrAB (Gunn et al., 2000). Ara4N modification of lipid A also contributes to AMP resistance in Proteus mirabilis, a frequent isolate in urinary tract infections including pyelonephritis. P. mirabilis mutants with loss of these Ara4N side groups demonstrate increased sensitivity to AMPs
(McCoy et al., 2001). Similar function and regulation of the Salmonella pmr AMP resistance locus is appreciated in the homologous operon of Yersinia pseudotubercolosis, an agent of food poisoning and enterocolitis (Marceau et al., 2003). Inducible AMP resistance under control of a PmrAB-like signal transduction system has also been documented in Pseudomonas aeruginosa and linked to Ara4N modification of lipid A (Moskowitz et al., 2004). During its adaptation to chronic colonization of the airway of cystic fibrosis patients, $P$. aeruginosa has been shown to synthesize a unique hexa-acylated lipid A containing palmitate and aminoarabinose conferring increased resistance to AMPs and increased inflammatory responses (Ernst et al., 1999b).

Another mechanism linked to AMP resistance in $S$. enterica has been mapped to the pagP gene, which functions to increase acylation of lipid $A$. Mutants with interruption of pagP demonstrate increased outer membrane permeability in response to AMPs (Guo et al., 1998). A pagP mutation in the intracellular respiratory tract pathogen Legionella pneumophila also leads to increased sensitivity to cationic AMPs and decreased replication (Robey et al., 2001). Acylation of lipooligosaccharide in the Gram-negative coccobacillus and human pathogen Haemophilus influenzae encoded by the htrB gene is a key factor in resistance to human $\beta$-defensin 2. Mutation of $h$ trB resulted in a greater than 45-fold increase in $H$. influenzae sensitivity to the AMP, a phenotype that was reversed by restoration of $h t r B$ in trans (Starner et al., 2002). H. influenzae also contains a phase-variable structure called phosphorylcholine (ChoP) on the oligosaccharide portion of LPS. Constitutive ChoPexpressing mutants exhibited 1,000-fold greater survival upon exposure to human cathelicidin LL-37 than mutants lacking ChoP (Lysenko et al., 2000). When the wildtype phase-variable $H$. influenzae strain was exposed to increasing concentrations of LL-37, progressive selection for the ChoP-positive phase was documented.

In summary, one common pattern of AMP resistance in both Gram-positive and -negative bacteria involves modification of normally anionic cell surface constituents with cationic molecules; the net effect of these substitutions is to repel positively-charged AMPs before they can reach the cytoplasmic membrane and disrupt its integrity (Fig. 2). Recently, additional studies have linked enzymes involved in biosynthesis and crosslinking of cell envelope components to AMP resistance in manners not necessarily involving altered charge. The ponA gene of GBS encodes penicillin-binding protein 1a (PBP1a), a high molecular weight bifunctional molecule with transglycosylase and transpeptidase activity. GBS ponA mutants are more sensitive to killing by both human cathelicidin and defensins (Hamilton et al., 2004). Phosphoglucomutase $(p g m)$ is required for lipopolysaccharide production in Bordetella bronchiseptica and cell-wall integrity in Streptococcus iniae; mutations in the pgm gene in either species lead to increased sensitivity to cationic AMP killing (Buchanan et al., 2005; West et al., 2000). Mycobacterium marinum mutants harboring transposon insertions in the beta-ketoacyl-acyl carrier protein synthase B gene (kasB) grew normally in vitro but were inhibited in their growth in human macrophages (Gao et al., 2003). Chemical 

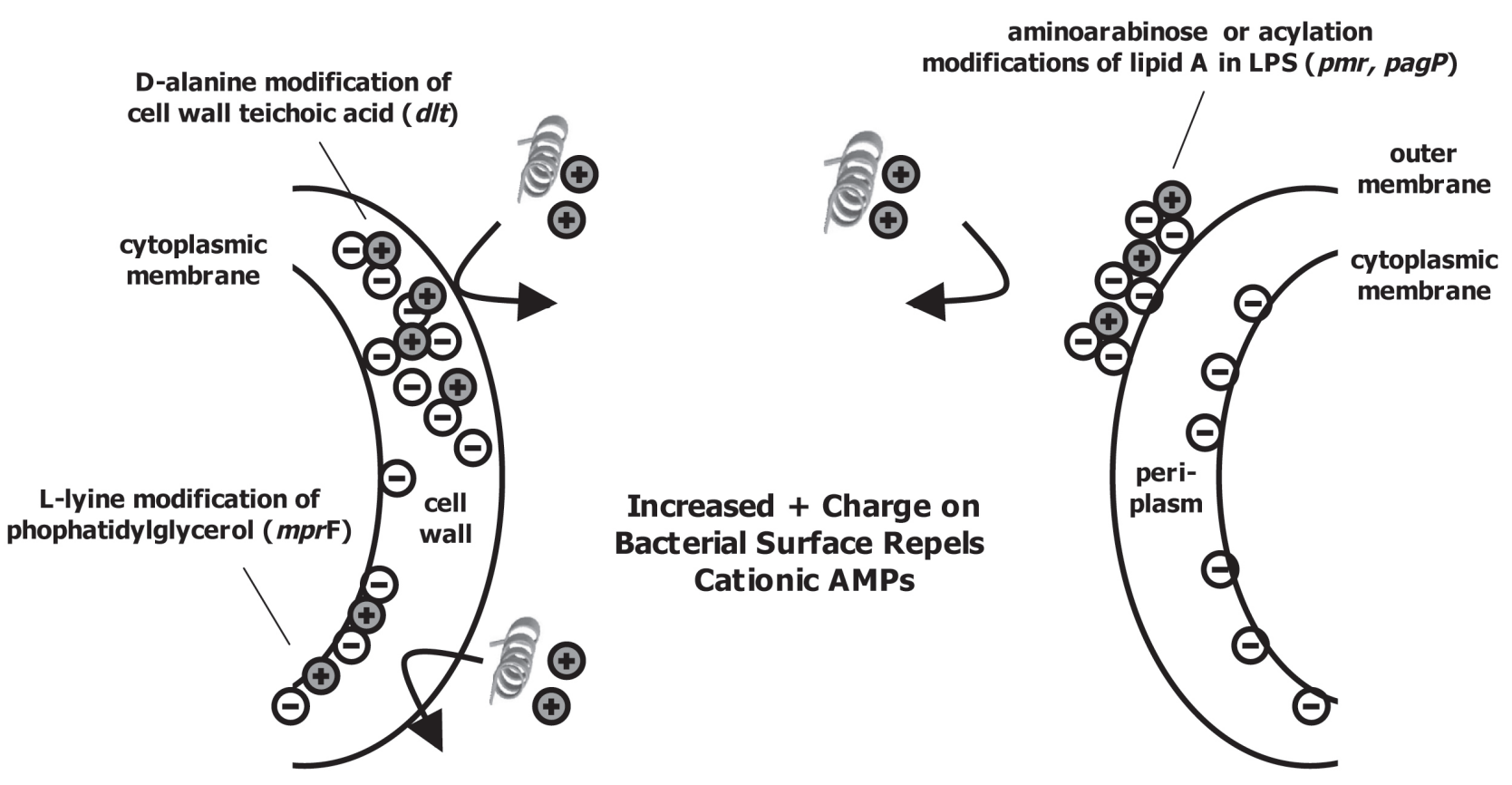

Gram + Bacterium

Gram - Bacterium

Fig. 2. Bacterial resistance to cationic antimicrobial peptides mediated by alterations in surface charge.

analysis revealed the kasB mutants synthesized unusually short mycolic acids, a unique family of fatty acids that contributes the low permeability of mycobacterial cell walls. The $M$. marinum kasB mutant was markedly more susceptible to killing by human defensins. Normal levels of AMP resistance could be restored to the $M$. marinum mutant by transformation with an expression vector containing kasB from Mycobacterium tuberculosis. These findings suggest that kasB may function similarly in $M$. tuberculosis to increase AMP resistance, and therefore could represent a novel target for treatment of a worldwide infection responsible for nearly 3 million deaths annually.

\section{External trapping of AMPs}

Another group of adaptations that allows certain pathogenic bacteria to avoid killing by AMPs involves binding or neutralization of the AMP. This form of resistance can be accomplished directly through the actions of a bacterial surface-associated or secreted protein, or indirectly by the induced release of AMP binding molecules from host cell surface (Fig. 3). When a significant proportion of the AMP released through the innate immune response is bound to the interfering molecules, insufficient quantities of the AMP reach the bacterial cell membrane to effect bacterial killing.

S. aureusproducesanexoproteincalledstaphylokinase (SK), which has been studied extensively due to its ability to activate host plasminogen. A recent study discovered that SK is able to directly bind the $\alpha$-defensins produced by human neutrophils. The consequence of the SK-AMP complex was a near complete inhibition of bactericidal effects on the $S$. aureus bacterium (Jin et al., 2004). The neutralizing effect of SK on the AMP was independent of plasminogen-binding site. Testing of a panel of $S$. aureus strains found that those producing SK were resistant to $\alpha$ defensins, and that addition of purified SK to SK-negative $S$. aureus cultures rescued them from $\alpha$-defensin killing (Jin et al., 2004). It is suggested that AMP-binding by SK may work together with dlt and mprF-mediated cellsurface charge modifications for neutrophil defensin resistance during $S$. aureus infections.

Group A Streptococcus (GAS) is an important Grampositive human pathogen associated with a wide range of mucosal and invasive infections, from simple pharyngitis and impetigo to potentially life-threatening necrotizing fasciitis and toxic shock syndrome. Strain variability in GAS is the result of hypervariable domains at the $\mathrm{N}$ terminus of the surface $M$ protein. M protein is anchored to the GAS cell wall by its C-terminus, then extends outward as a coiled-coil dimer to forms a fimbrial coating over the bacterial surface. M protein is recognized as a virulence factor with antiphagocytic and host cell adherence properties encoded in its conserved $\mathrm{C}$-terminal and central domains, but the function of the hypervariable domain has been less well studied. Of the more than 150 GAS Mprotein serotypes, a globally disseminated M1 serotype clone has been associated with a resurgence of severe, invasive GAS infections documented since the mid1980s (Efstratiou, 2000). Analysis of a collection of GAS clinical isolates from the Centers from Disease Control found that M1 strains exhibited significantly higher levels of resistance to human cathelicidin LL-37 than strains belonging to other $M$ serotypes associated only with superficial infections (Lauth et al., 2004). A knockout of the emm1 gene encoding $M$ protein increased the sensitivity of M1 GAS to LL-37, while heterologous expression of the M1 protein in M49 GAS or Lactococcus lactis caused the transformed bacteria to gain cathelicidin resistance. 


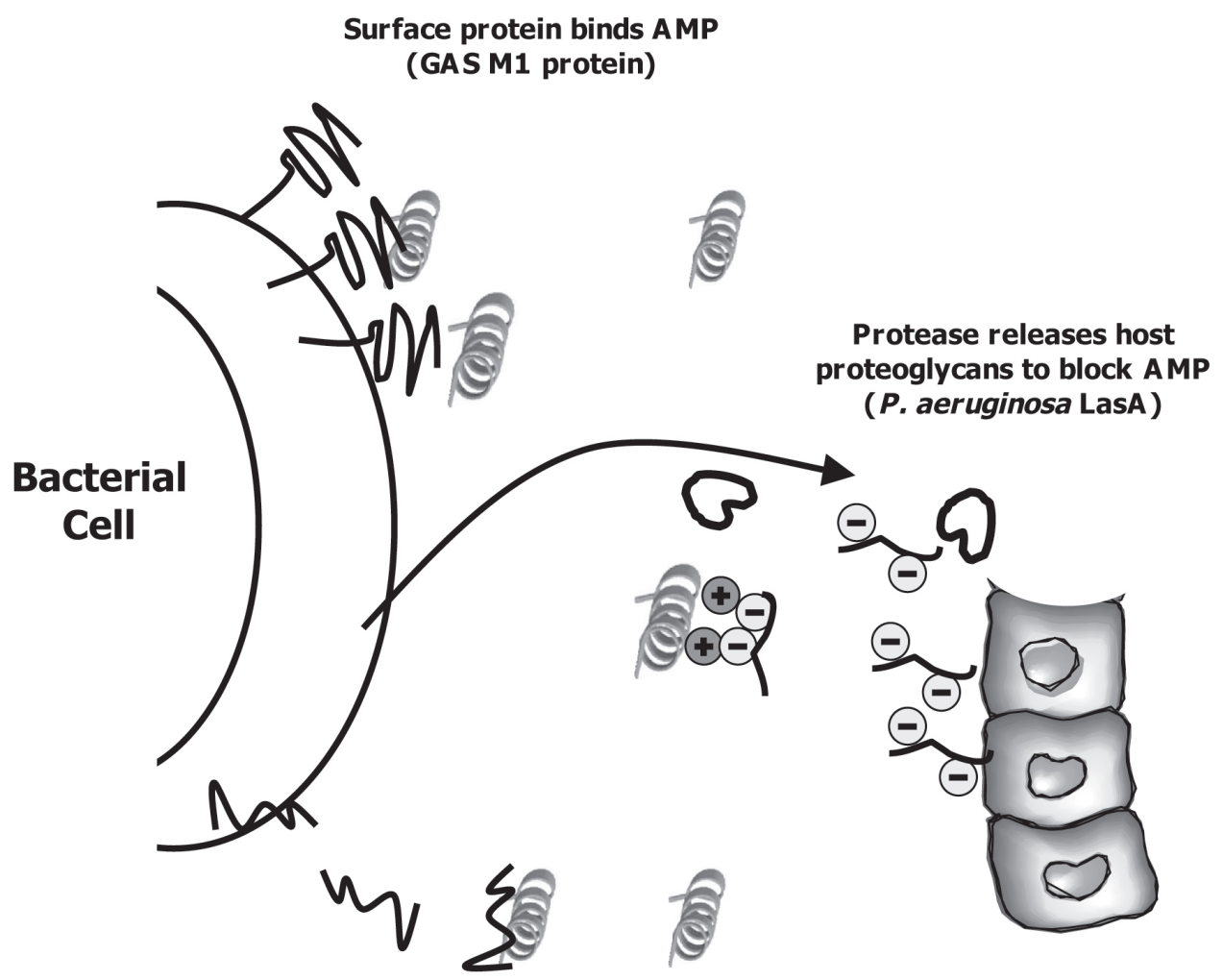

\section{Secreted protein binds AMP (GAS SIC protein or S. aureus staphylokinase)}

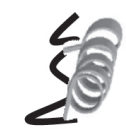

Fig. 3. Bacterial resistance to cationic antimicrobial peptides mediated by mechanisms for trapping and inactivation.

Studies with recombinant peptide fragments mapped the AMP binding property to the hypervariable $\mathrm{C}$-terminus of M1 protein, a function lacking in the same domain from GAS M49 protein (Lauth et al., 2004). Virulent GAS M1 strains secrete a protein called $\mathrm{SIC}$ is absent in the vast majority of noninvasive GAS strains. SIC was found to bind and inactivate LL-37 and human $\alpha$-defensin, protecting the bacterium from their antimicrobial action (Frick et al., 2003). In these studies, a SIC-negative M1 GAS mutant showed increased sensitivity to AMP killing.

Another mechanism by which bacteria appear to trap and inactivate AMPs is by exploitation of negatively charged proteoglycan molecules that decorate the surfaces of host epithelial cells. For example, extracellular proteases secreted by the human pathogens GAS, Enterococcus faecalis and $P$. aeruginosa degrade decorin and other cell-surface proteoglycans, thereby releasing dermatan sulfate. Free dermatan sulfate can then in turn bind and inactivate human $\alpha$-defensins (Schmidtchen et al., 2001). P. aeruginosa also enhances shedding of the heparan sulfate proteoglycan syndecan-1 from various host cells; this phenotype can serve to neutralize cationic AMPs and has been attributed to the actions of a 20$\mathrm{kDa}$ protein virulence factor LasA (Park et al., 2000). Given these observations regarding the AMP neutralizing effects of host proteoglycans, it is interesting to speculate whether surface exposed bacterial carbohydrates could play a role in AMP resistance. For example, certain human pathogens possess exopolysaccharide capsules composed of hyaluronan (e.g. GAS) or chondroitin (e.g. Pasteurella multocida), or enriched in sialic acid moieties (e.g. GBS, Neisseria meningitides). Acapsular mutants in all these species loose virulence, a phenomenon classically attributed to interference with complementmediated opsonphagocytosis. It will be interesting in future studies to explore a potential role of acidic sugar capsules in AMP trapping as an additional selective advantage. Such a correlation has recently been suggested for the pathogen Klebsiella pneumoniae, as mutants lacking capsular polysaccharide were demonstrated to be more susceptible to a variety of cationic AMPs including human $\alpha$ - and $\beta$-defensins (Campos et al., 2004).

\section{Active efflux of AMPs}

Energy-driven drug efflux systems are increasingly recognized as mechanisms of bacterial resistance to conventional pharmaceutical antibiotics. The major categories include pumps energized by ATP and those driven by proton motive force I (Levy, 2002). The efflux pumps may recognize a limited number of substrates, such as mefA in GAS for macrolide efflux. or a broad range of antimicrobials, for example the mexCD-oprJ multidrug efflux pump in $P$. aeruginosa. Exposure to antibiotics promotes the mutational overexpression of active or silent multidrug transporters, leading to increased antibiotic resistance without a requirement for acquisition 
of multiple, specific resistance determinants (Zgurskaya, 2002). Evidence indicates that in a few cases, efflux systems may also contribute to the intrinsic resistance of certain human pathogens to the action of cationic AMPs of the innate immune system (Fig. 4).

Neisseria gonorrhoeae is a major agent of sexually transmitted infections in humans including urethritis and cervicitis. N. gonorrhoeae express an energydependent efflux system MtrCDE that expels hydrophobic antimicrobial agents and increases resistance to antibiotics such as penicillin and erythromycin (Veal et al., 2002). Genetic and biochemical evidence has demonstrated that gonococcal resistance to protegrin-1 and human cathelicidin LL-37 is modulated by overexpression of the mtr genes (Shafer et al., 1998). S. enterica mutants with a defect in the sap locus sharing homology with potassiumlinked efflux systems in E. coli are more susceptible to the cationic AMP protamine (Parra-Lopez et al., 1994), while a homologous locus in $\mathrm{H}$. influenzae promotes resistance to $\beta$-defensin (Mason et al., 2005). Certain $S$. aureus strains harbor a multiresistance plasmid pSK1 that encodes the QacA efflux pump. S. aureus positive for qacA exhibit higher levels of resistance to a cationic rabbit platelet AMP, tPMP, but not to other structurally distinct AMPS including human $\alpha$-defensin and protamine (Kupferwasser et al., 1999).

\section{Proteolytic degradation of AMPs}

Many pathogenic bacterial species produce proteases or peptidases that contribute to disease pathogenesis by altering host substrates or by inactivating key components of the host immune response. Examples include cleavage of IgA by S. pneumoniae (Weiser et al., 2003), inactivation of complement C5a by GBS (Hill et al., 1988), or degradation of chemokine interleukin-8 by GAS (Hidalgo-Grass et al., 2004). One of the reasons that mammalian AMPs have remained such an effective and broad-spectrum component of innate immune defense is their relative resistance to proteolytic degradation, for example proline-rich sequences in many cathelicidin peptides resist attack by serine proteases because proline prevents cleavage of the scissile bond (Shinnar et al., 2003). Nevertheless, certain important pathogens of humans secrete, or express on their surface, proteases that recognize and cleave cationic AMPs, and therefore allow the bacteria avoid the microbicidal action of the host peptide (Fig. 4).

The human cathelicidin LL-37 is the target of proteases from the important human pathogens GAS, $P$. aeruginosa, $P$. mirabilis and Enterococcus faecalis (Schmidtchen et al., 2002). In some experiments, cell culture supernatants prepared from GAS expressing cysteine proteinase, $P$. mirabilis expressing a $50 \mathrm{kDa}$

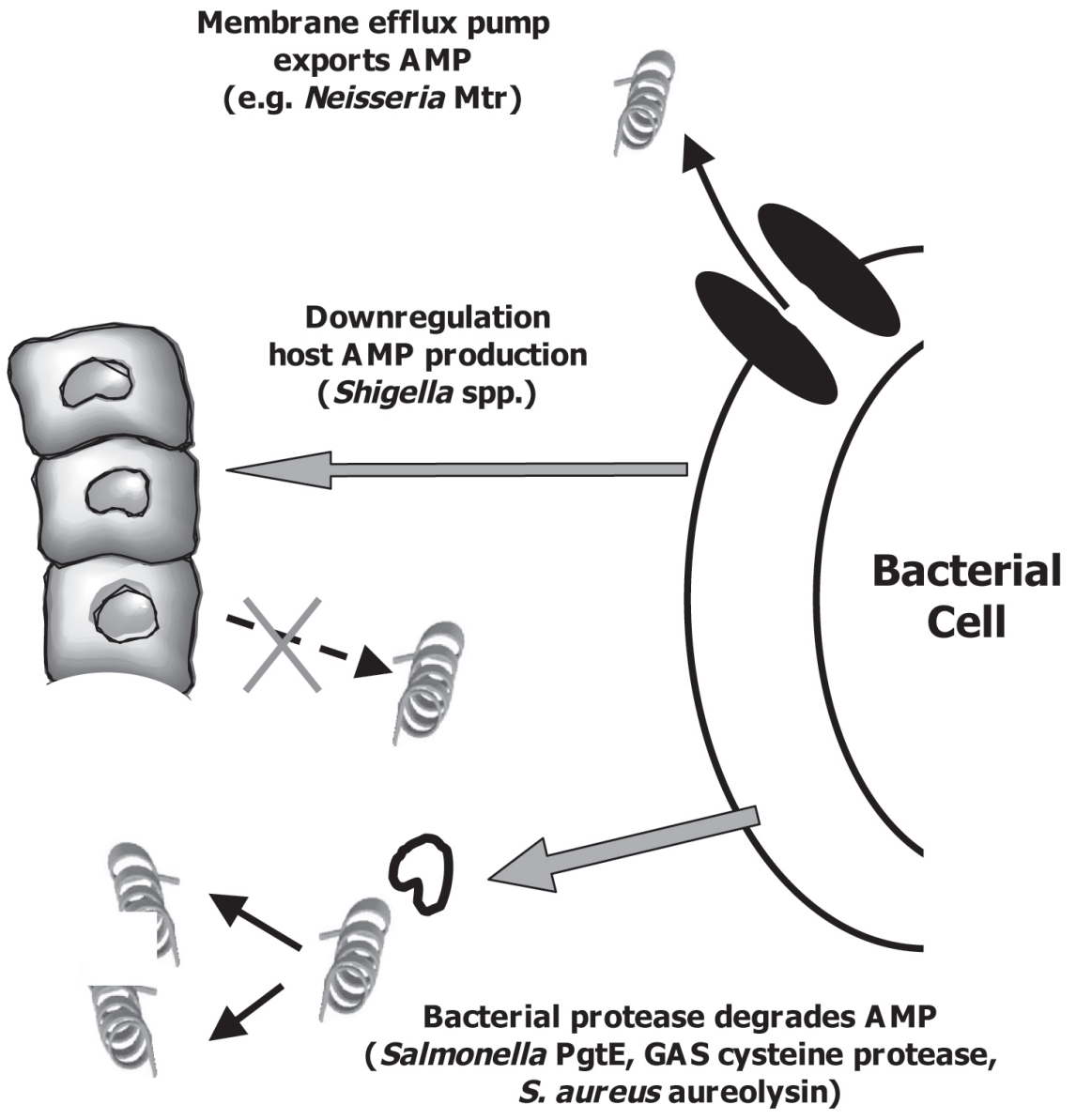

Fig. 4. Bacterial resistance to cationic antimicrobial peptides mediated by efflux pumps, proteolytic activation, or downregulation of host production. 
metalloprotease, or $E$. faecalis expressing gelatinase were found to degrade LL-37, while LL-37 was preserved when specific inhibitors of each protease were added to the assay. More extensive mass spectrometry analysis on LL-37 degradation by $P$. aeruginosa elastase mapped the proteolytic activity to initial cleavages at Asn-Leu and Asp-Phe, and ex vivo studies showed that expression of the bacterial elastase enhanced survival of $P$. aeruginosa in a wound fluid environment (Schmidtchen et al., 2002). The metalloprotease aureolysin of $S$. aureus cleaves and inactivates LL-37 in a concentration and time-dependent manner, and a inverse correlation can be established between the level of aureolysin production of $S$. aureus strains and their susceptibility to LL-37 killing (SieprawskaLupa et al., 2004).

An outer membrane protease of $S$. enterica known as PgtE can specifically cleave C18G, an $\alpha$-helical cationic AMP. Mutagenesis of the pgtE rendered the $S$. enterica strain more susceptible to $\mathrm{C} 18 \mathrm{G}$ and the human cathelicidin LL-37 (Guina et al., 2000). Proteases produced by $E$. coli and $S$. aureus inactivate lactoferricin $B$, a cationic AMP derived from the $\mathrm{N}$-terminus of mammalian lactoferrin (Ulvatne et al., 2002). Culture supernatants or purified proteases of the human periodontal pathogens Porphyromonas gingivalis and Prevotella spp. are known to inactivate cationic AMPs such as cecropin B and brevinin (Devine et al., 1999), but their effect on human AMPs has not been determined.

\section{Bacterial gene regulation and AMP resistance}

A number of important human bacterial pathogens have global regulatory networks for coordinate upregulation or downregulation of virulence factors dependent on growth phase or upon environmental cues encountered in different tissue niches of their host. Well-studied examples include the PhoP/PhoQ two-component regulatory system of $S$. enterica, the agr-encoded quorom sensing locus of $S$. aureus, the response regulator ArcA of Vibrio cholerae or the covRS locus of GAS. Recent evidence indicates that some of the complex phenotypes involved in determining bacterial resistance to AMPs appear to have come under transcriptional control by such global regulation systems.

The PhoP/PhoQ two-component system of $S$. enterica governs transcription of at least 25 genetic loci in response to changes in the extracellular concentration of magnesium and calcium, such as those encountered within the phagolysome of host macrophages. The PhoP/PhoQ regulators promote remodeling of the bacterial envelope, including upregulation of enzymes that modify LPS charge (Ernst et al., 1999a; Ernst et al., 2001). Mutations in the phoPQ operon decrease $S$. enterica survival within macrophages and increase susceptibility to cationic AMPs and acid pH (Garcia Vescovi et al., 1994). One of the targets of PhoP/PhoQ upregulation is the PgtE outer membrane protease that degrades $\alpha$-helical AMPs (Guina et al., 2000), while another is the pag $\mathrm{P}$ gene required for lipid A acylation (Guo et al., 1998). A homologous $\mathrm{PhoP} / \mathrm{PhoQ}$ regulatory system in $P$. aeruginosa regulates resistant to cationic AMPs including cathelicidin LL-37 in response to low magnesium conditions (Macfarlane et al., 2000; McPhee et al., 2003). In both S. enterica and $P$. aeruginosa a second two-component regulatory system called PmrA/PmrB is involved in upregulating AMP resistance through an increase in the gene expression for Ara4N incorporation in LPS (Gunn et al., 2000; McPhee et al., 2003).

The extracytoplasmic sigma factor RpoE is required for Salmonella resistance to the murine $\alpha$-defensin cryptdin-4, and the expression of the rpoE gene is induced adaptively when the bacterium is exposed to the peptide (Crouch et al., 2005). A number of other S. enterica genes with homology to transcriptional regulators (virK, somA, $r c s \mathrm{C}$ ) have recently been identified and linked to resistance against killing by the cationic AMP polymixin B. It is hypothesized but not proven that these loci contribute to remodeling of the bacterial outer membrane in response to the host environment (Detweiler et al., 2003). The thermoregulated transcription factor PrfA of $L$. monocytogenes controls the expression of asyet-undefined phenotypic properties that influence the susceptibility of the organism to defensins (LopezSolanilla et al., 2003). Lastly, the dlt operon encoding Dalanylation of techoic acid in is among the agr-regulated genes identified in transcriptional profiling of $S$. aureus (Dunman et al., 2001), but a link between the agr locus and AMP resistance is not conclusively established.

It is likely that future studies will identify more pathways and levels of transcriptional control for genes encoding AMP resistance. Intuitively, a bacterial species must seek to strike a balance between surviving innate immune clearance and the potential metabolic expenditures required to undergo the resistance-conferring biosynthetic modifications. An exciting observation in examination of these mechanisms is the ability of the bacteria to upregulate the $\mathrm{PhoP} / \mathrm{PhoQ}$ or $\mathrm{PmrA} / \mathrm{PmrB}$ signaling cascades upon sensing the presence of subinhibitory concentrations of cationic AMPs (Bader et al., 2003; McPhee et al., 2003). In effect, these pathogenic bacteria can adapt themselves in real time to survive against the challenges of AMP-mediated innate immune clearance mechanisms.

\section{Bacterial regulation of host AMP production}

One of the elegant features of AMPs in mammalian innate immunity are their inducibility. Only low levels of the defense peptides are generated by epithelia and leukocytes at baseline, yet their expression can be dramatically induced in response to infectious challenge. For example, immunostaining demonstrates that subcutaneous infections with the Gram-positive pathogen GAS provoke marked increases in local expression of cathelicidin both mice and humans (Dorschner et al., 2001; Lauth et al., 2004). In porcine and bovine models, leukocyte expression of cathelicidin is specifically induced in response to Gram-negative bacterial infection or LPS (Tomasinsig et al., 2002; Wu et al., 2000). Recent studies of human airway epithelial cells indicate that $\beta$-defensin expression can be induced by cell wall lipoteichoic acid in a process involving Toll-like receptor-2 recognition and activation of NFKB signal transduction pathways (Birchler et al., 2001; Wang et al., 2003), and the epidermal $\beta$ defensin-2 response to LPS is further augmented by mononuclear cell production of interleukin-1 (Liu et al., 2003). 
Interference with or suppression of such host pathways for AMP induction appears to be another mechanism by which certain pathogenic bacteria can avoid innate immune clearance. For example, while several bacterial species strongly induce human $\beta$-defensin-2 expression from skin epithelial cells, the common skin pathogen GAS is a very poor and variable inducer of the AMP (Dinulos et al., 2003). This observation suggests that GAS avoids the initial pattern recognition receptors or somehow actively downregulates the $\beta$-defensin- 2 induction pathway. An elegant study of the human gastrointestinal pathogen Shigella dysenteriae found that expression of the AMPs LL-37 and $\beta$-defensin- 1 is downregulated at the transcriptional level in the early stages of infection (Islam et al., 2001) (Fig. 4). The downregulation was first observed in biopsies from humans with bacillary dysentery then confirmed in epithelial and monocyte cell culture experiments; plasmid DNA from $S$. dysenteriae appeared to be one molecule contributing to the inhibition.

In contrast to inhibiting host AMP production, an alternative bacterial survival strategy can involve the stimulation of host mechanisms that function to counterregulate the AMP response. Such a process may take place in the lungs of patients with cystic fibrosis, where the pathogen $P$. aeruginosa stimulates the accumulation of the cysteine protease cathepsins $B, L$ and $S$ in the airway fluid. These proteases degrade and inactivate human $\beta$-defensins 2 and 3 , favoring the chronic bacterial infection and colonization characteristic of the disease (Taggart et al., 2003).

Finally, it is becoming apparent that regulation of skin and mucosal AMP defenses will only be fully understood in the greater context of the normal (nonpathogenic) microflora. Over the years, much interest has been focused on how loss of tolerance to normal gut microflora may play a role in the pathogenesis of inflammatory bowel disease (Landers et al., 2002), or conversely, how oral administration of commensal bacteria may have therapeutic immunomodulatory ("probiotic") effects (Gionchetti et al., 2002). The recent discovery of the antimicrobial properties of angiogenins, cationic peptides produced in Paneth cells of the intestinal crypts, is interesting in this regard. In the murine model, angiogenin-4 production is strongly induced by the normal microflora constituent Bacteroides thetaiotaomicron (Hooper et al., 2003), a property which distinguishes it from other intestinal AMPs. Though the $B$. thetaiotaomicron bacterium itself is relatively resistant to angiogenin-4 action, the peptide shows killing activity against a number of Gram-positive and -negative pathogens. The fascinating implication of these studies is that bacteria of the normal flora may play a critical role in establishing AMP defenses, such that perturbations in the host-commensal relationship could adversely impact the innate immune barrier of the gut mucosa.

\section{Correlation of AMP resistance with virulence}

This review has identified several phenotypic properties of pathogenic bacteria that serve directly or indirectly to increase their resistance to cationic AMPs in vitro. In the realm of innate immunity, these phenotypes would mean little without evidence that bacterial AMP resistance contributes to disease potential. Such a link has firmly been established, and represents a byproduct of two lines of investigations: (a) animal studies that establish an essential role of mammalian AMP production in innate defense against bacterial infection, and (b) studies with isogenic mutant bacteria that associate in vitro AMP sensitivity or resistance to in vivo pathogenicity.

Definitive proof that the endogenous expression of AMPs contributes to mammalian innate immunity was achieved only recently through the generation and analysis of knockout mice. A mouse deleted for the Cnlp gene encoding the sole mouse cathelicidin mCRAMP exhibits normal growth and development and produces normal numbers of circulating leukocytes (Nizet et al., 2001). However, blood and isolated mast cells from Cnlp-l- mice are notably deficient in killing the pathogen S. pyogenes, and knockout mice challenged with this bacterium develop much more severe and persistent necrotizing skin infections than their wild-type littermates (Di Nardo et al., 2003; Nizet et al., 2001). Compared to normal littermates, Cnlp-l- mice are more susceptible to intestinal colonization, epithelial cell damage, and systemic dissemination of the murine intestinal pathogen Citrobacter rodentium, establishing cathelicidin as an important component of innate immune defense in the colon (limura et al., 2005). A mCRAMP-sensitive mutant of the intracellular pathogen $S$. typhimurium showed enhanced survival in macrophages from CInp-/- mice, indicating cathelicidin contributes to killing within the phagolysosome (Rosenberger et al., 2004). Defb1, a murine homologue to human $\beta$-defensins, is expressed on respiratory epithelium. The Defb1-/- mouse showed delayed clearance of $H$. influenzae from the lung and increased bladder colonization with $S$. aureus. (Morrison et al., 2002; Moser et al., 2002). Similarly, mice deficient in the metalloproteinase matrilysin required for cryptdin ( $\alpha$-defensin) activation possess decreased enteric microbicidal activity against orally administered Salmonella (Wilson et al., 1999).

Complementary investigations indicate that augmentation of AMP levels on host mucosal surfaces can retard bacterial colonization and enhance resistance to infection. In these experiments, increased AMP levels are achieved through gene therapy or by exogenous administration of purified or recombinant peptide. For example, the airway surface fluid of cystic fibrosis xenografts failed to kill $P$. aeruginosa or $S$. aureus; however, exposure of the xenografts to an adenovirus expressing human cathelicidin restored bacterial killing to normal levels. Mice treated intratracheally with this adenoviralAMP vector had a lower bacterial load and diminished inflammatory response after $P$. aeruginosa challenge. In lambs with pneumonia, intratracheal administration of cathelicidin AMP reduced the concentration of bacteria in pulmonary tissues and fluid (Brogden et al., 2001). Topical administrations of a gel containing a cationic AMP has also been shown to decrease Trichomonas vaginalis colonization of vaginal epithelium in mice (Lushbaugh et al., 2000), block $P$. aeruginosa superinfection of experimental burns in rats (Chalekson et al., 2002), and inhibit development of wound infections in pigs (Ceccarelli et al., 2001). Transgenic mice expressing human intestinal defensin-5 show marked resistance to oral challenge with 
Salmonella (Salzman et al., 2003); similarly, transgenic mice expressing porcine cathelicidin are less susceptible to GAS skin infection (Lee et al. 2005). Lastly, dermal wounds in nude mice can be treated with grafting of a genetically-engineered epidermal sheet expressing human $\beta$-defensin 3 , which functions to produce augmented levels of the defense peptides (Sawamura et al., 2005).

Given the mounting direct evidence that AMPs play a critical role in innate mucosal defense, the correlation of in vivo bacterial AMP resistance phenotypes to pathogenic potential is afforded considerable credence. Direct comparisons of resistant wild-type bacteria with isogenic, AMP-sensitive mutants have been performed for each of the major classes of resistance mechanisms, providing validation of the adaptive benefit of these phenotypes for survival of the organism in the mammalian host.

Dlt- and MprF- mutants of $S$. aureus lack D-alanine and L-lysine cell wall modifications, respectively, and are more sensitive to AMP activity in vitro. Both types of mutants are more readily phagocytosed by neutrophils and less able to establish systemic infection in mice (Kristian et al., 2003a; Kristian et al., 2003b; Peschel et al., 2001). A Dit- mutant of $L$. monocytogenes possesses a 10,000fold greater LD50 than the wild-type strain in murine infection (Abachin et al., 2002), and a DIt- GBS strain was severely impaired in both mouse and neonatal rat models (Poyart et al., 2003). S. enterica mutants in PmrA lack the aminoarabinose modification of LPS associated with AMP resistance and are less virulent than wild-type following oral administration in a murine enteric infection model; however, the mutants are equally virulent when inoculated systemically (Gunn, 2001; Gunn et al., 2000), indicating a specific role for the phenotype in resistance to mucosal defenses. Lipid A acylation encoded by a pagP homologue in Legionella is required for AMP resistance and for efficient lung colonization in mice (Robey et al., 2001). Thus in both Gram-positive and -negative bacteria, specific cell surface modifications resulting in decreased negative charge and enhanced resistance to cationic AMPs are associated with greater pathogenic potential.

Bacterial resistance achieved through external trapping of AMPs can also be correlated to increased pathogenicity. GAS mutants lacking the surfaceassociated M1 protein or secreted SIC protein are more easily cleared in vivo upon mouse challenge (Frick et al., 2003), however these proteins have additional properties of complement interference. Staphylococcal strains producing AMP-binding staphylokinase were protected against the bactericidal effect of $\alpha$-defensins in murine arthritis model (Jin et al., 2004). The pathogen $P$. aeruginosa, through its virulence factor LasA, enhances in vitro shedding of the proteoglycan syndecan-1 which interferes with AMP function (Park et al., 2000). Newborn mice deficient in syndecan-1 resist $P$. aeruginosa lung infection but become susceptible when treated with syndecan-1 derived heparan sulfate chains (Park et al., 2001).

N. gonorrhoeae lacking the MtrCDE efflux system for AMP resistance were deficient in their ability to establish genital tract infection in mice (Jerse et al., 2003). Nontypeable $H$. influenzae with a deficiency in the sap AMP transport locus had attenuated survival in a chinchilla model of otitis media (Mason et al., 2005). The PhoP/PhoQ regulatory system controls multiple virulence phenotypes in Salmonella spp., including a $\mathrm{K}^{+}$coupled AMP efflux pump and the AMP protease, PgtE. $S$. enterica mutants in the $P h o P / P h o Q$ regulatory system are more sensitive to AMP killing and significantly less virulent in the murine gastrointestinal infection model (Parra-Lopez et al., 1994). The inner membrane protein Mig-14 inhibits binding of CRAMP to Salmonella by an unknown mechanism (Brodsky et al., 2002). Salmonella mutants deficient in Mig-14 are more susceptible to murine cathelicidin mCRAMP, impaired in their survival within activated macrophages, and unable to establish chronic splenic and hepatic infection after orogastric administration (Brodsky et al., 2005).

The studies above have used mutagenesis to target bacterial phenotypes associated with AMP resistance in vitro and determined experimentally that loss of the resistance phenotype translates to decreased virulence in vivo. Recently, a study of GAS pathogenicity approached the issue from the opposite perspective. This bacterium is normally sensitive to cathelicidin killing, but resistant mutants can be selected by serial exposure to cathelicidin in vitro. Upon subcutaneous inoculation of mice, the AMP-resistant $S$. pyogenes mutant was found to induce more severe necrotizing skin infections than the wildtype parent strain. While the sensitive wild-type strain was killed in whole blood from normal mice, the resistant mutant proliferated. As predicted, no difference between wild-type and AMP-resistant mutant bacteria were seen for growth in blood from cathelicidin-deficient mice (Nizet et al., 2001).

\section{Altered AMP production and opportunistic infection} The contribution of intrinsic bacterial AMP resistance to infectious disease pathogenesis is exaggerated when local AMP production is impaired. Recent studies have determined that decreased AMP production or local interference with AMP function may explain the increased infectious risks associated with certain chronic diseases or epidermal injuries. In such settings, a lower effective concentration of AMP allows survival or proliferation of bacterial species that would normally be eradicated, creating a potential for opportunistic infection.

Kostmann syndrome is a rare inherited disorder characterized by severe congenital neutropenia. These patients are treated with granulocyte-colony stimulating factor to increase neutrophil counts within the normal range; nevertheless, they still experience frequent infections and develop periodontal disease. Functional analysis of neutrophils isolated from these patients demonstrated normal oxidative burst function, but revealed a lack of measurable cathelicidin and diminished levels of $\alpha$-defensins (Putsep et al., 2002). The chronic inflammation of cystic fibrosis is associated with increased levels of AMP in respiratory tract secretions. However, the cystic fibrosis airway surface fluid is diminished in its ability to kill bacteria. This defect is reflected in chronic high level bacterial colonization and recurrent pneumonia with low virulence organisms such as $P$. aeruginosa. The bacterial killing ability of cystic fibrosis airway fluid is 
restored when its salt concentration is lowered to normal levels, suggesting the abnormally high salt concentrations produced by the defective cystic fibrosis transmembrane conductance regulator may be responsible (Smith et al., 1996). The bacterial killing ability of epithelial-derived AMPs such as the human $\beta$-defensins and cathelicidin are inactivated by high salt concentrations (Bals et al., 1998; Goldman et al., 1997), suggesting a defect in this component of innate immune defense may be responsible for the chronic pulmonary infections seen in cystic fibrosis patients.

Crohn's disease (CD) is a chronic disease of the intestinal mucosa characterized by granulomatous inflammation. Abnormal response to intestinal bacteria has been postulated to play a role in development of $\mathrm{CD}$, including culture studies identifying Mycobacterium avium, subsp. paratuberculosis in the blood of CD patients (Naser et al., 2004). The inflamed colonic mucosa in CD is characterized impaired of constitutive and inducible production of $\beta$-defensins (Wehkamp et al., 2005). When CD affects the small intestine, diminished defensin expression is observed in Paneth cells of the ileum, and this deficiency is even more pronounced in the subset of CD patients harboring a mutation in the gene encoding the Nod2 protein (Wehkamp et al., 2005). Nod2 is a pattern recognition receptor for bacterial muramyl dipeptide that is required for the expression of the cryptdin group of intestinal $\beta$-defensins. The importance of Nod2 in innate mucosal immunity of the intestine has recently been explored using Nod2-deficient mice. These animals are susceptible to bacterial infection via the oral route but not through intravenous or intraperitoneal challenge (Kobayashi et al., 2005).

Differential expression of AMPs appears to play a determinative role in the susceptibility of chronic inflammatory skin disorders to infectious complications. In psoriasis, cathelicidin and $\beta$-defensin levels are elevated and secondary infection is rare, whereas in atopic dermatitis cathelicidin expression of the same AMPs is deficient and bacterial or viral superinfection is common. Especially relevant in this regard is the proven activity of human cathelicidin against $S$. pyogenes (Dorschner et al., 2001) and the synergistic activity of human cathelidicin and $\beta$-defensin against $S$. aureus, the leading agents of superficial and invasive skin infection in humans. Expression of $\beta$-defensin is absent in full-thickness burn wounds and blister fluid from partial thickness burns (Ong et al., 2002), evidence of an innate immune defect that may be contribute in the greatly increased risk of burn wound infection and sepsis. In chronic ulcers, cathelicidin levels are low and absent in the ulcer edge epithelium (Heilborn et al., 2003). Cathelicidin AMPs are important in successful wound closure and defects in their production can be correlated with development of chronic ulcers.

\section{Conclusions and future perspective}

AMPs represent an evolutionarily ancient defense strategy now recognized to play an important role in human innate immunity. Not all bacteria are created equal when it comes to AMP susceptibility, and it appears that the ability to resist AMP killing is a discriminating feature of several important human pathogens. Bacteria such as $S$. aureus and Salmonella spp. that generally exhibit AMP resistance would be predicted to possess a survival advantage on compromised epithelium, in deeper body tissues, and in the phagolysosomes of neutrophils and macrophages. This concept is supported by the fact that $S$. aureus is the most common cause of human wound infections and deep-tissue abscesses, while Salmonella spp. are leading agents of chronic systemic infections (enteric and typhoid fever) that can develop in otherwise healthy individuals. In contrast, bacteria more sensitive to AMPs, such as E. coli, can occupy a niche on mucosal surfaces with local or toxin-mediated disease effects, generally invading deep tissues only in groups with broader defects in innate or acquired immunity (e.g. neonates, the elderly or chemotherapy patients).

The selective pressure toward bacterial AMP resistance is reflected in the broad diversity of AMP resistance mechanisms that have been elucidated in recent molecular microbiologic investigations (summarized in Table 1). One path to resistance shared by several bacterial species and achieved in various fashions involves modification of the normal anionic constituents of their cell surfaces to repulse rather than attract cationic AMPs. Alternative resistance mechanisms include the binding, active efflux or proteolytic activation of AMPs before they reach their cell membrane target of action. Corroborating the importance of AMPs in host defense, isogenic bacterial mutants with decreased AMP resistance are less virulent than their wild-type parent strains in animal models of invasive bacterial infection.

Why do so many bacterial species remain sensitive to AMP action? One may speculate that some mutations conferring increased AMP resistance could involve biochemical modifications that are metabolically too expensive for maintenance. Additionally, such mutations may not prove advantageous to the organism in epithelial colonization or host-to-host transmission, where even greater selective pressures exist. The balance between surviving innate immune clearance and metabolic expenditure is reflected in the adaptations of several bacteria toward inducible resistance, in which exposure to low levels of the AMPs leads to upregulation of resistance phenotypes (Bader et al., 2003; McPhee et al., 2003; Nizet et al., 2001; Shelburne et al., 2005).

It is interesting to ponder why bacterial species that are normally sensitive to AMP killing sometimes produce serious infections in humans without known immunodeficiency. Certain pathogenic species (e.g. Streptococcus pneumoniae, Neisseria meningitides) possess mechanisms for epithelial cell invasion and transcytosis that could allow bloodstream and deep tissue access without causing the barrier injury that would trigger host AMP production in the local tissues. For these and many other human pathogens, surface proteins and/or polysaccharide capsules impede phagocytic uptake, thus avoiding a second site of AMP action within the phagolysosome. For most agents of human bacterial infection, the number of individuals colonized asymptomatically greatly exceeds the low incidence of invasive disease. Is it possible that in rare events a quantum "phase shift" to higher AMP resistance allows invasion? Alternatively, do some patients have subtle congenital or acquired defects in their specific ability to mount an appropriate AMP response to minor 







\begin{tabular}{|c|c|c|c|c|c|}
\hline AMP Resistance Phenotype & Gene(s) & AMPs Affected & Organism(s) & Virulence Role * (model system) & Selected Reference \\
\hline \multicolumn{6}{|l|}{ Alteration of Host Processes } \\
\hline $\begin{array}{l}\text { Downregulate AMP transcrip- } \\
\text { tion }\end{array}$ & Unknown & Caths & Shigella dysenteriae & Shigella dysentery (humans) & (Islam et al., 2001) \\
\hline Stimulation of host cathepsins & Unknown & Defensins & $\begin{array}{l}\text { Pseudomonas aeru- } \\
\text { ginosa }\end{array}$ & Unknown & (Taggart et al., 2003) \\
\hline \multicolumn{6}{|l|}{ Regulatory Networks } \\
\hline Two-component regulator & $\begin{array}{l}\text { phoP/ } \\
\text { phoQ }\end{array}$ & $\begin{array}{l}\text { Defensins, } \\
\text { protamine }\end{array}$ & $\begin{array}{l}\text { Salmonella enterica } \\
\text { Pseudomonas aeru- } \\
\text { ginosa }\end{array}$ & Gastrointestinal infection (mice) & $\begin{array}{l}\text { (Ernst et al., 2001) } \\
\text { (Macfarlane et al., 2000) }\end{array}$ \\
\hline Two-component regulator & $\begin{array}{l}p m r A \\
p m r \mathrm{~B}\end{array}$ & $\begin{array}{l}\text { Defensins, } \\
\text { Polymyxin B }\end{array}$ & $\begin{array}{l}\text { Salmonella enterica } \\
\text { Pseudomonas aeru- } \\
\text { ginosa }\end{array}$ & Gastrointestinal infection (mice) & $\begin{array}{l}\text { (Gunn et al., 2000) } \\
\text { (McPhee et al., 2003) }\end{array}$ \\
\hline Extracytoplasmic sigma factor & rpoE & Defensins & Salmonella enterica & Gastrointestinal infection (mice) & (Crouch et al., 2005) \\
\hline $\begin{array}{l}\text { Thermoregulated transcription } \\
\text { factor }\end{array}$ & prfA & Defensins & $\begin{array}{l}\text { Listeria monocyto- } \\
\text { genes }\end{array}$ & Gastrointestinal infection (mice) & $\begin{array}{l}\text { (Lopez-Solanilla et al., } \\
\text { 2003) }\end{array}$ \\
\hline \multicolumn{6}{|c|}{$\begin{array}{l}\text { Abbreviation: Cath }=\text { cathelicidin. }{ }^{*} \text { Virulence roles demonstrated in animal models with isogenic mutants often performed in independent studies and } \\
\text { not conclusively linked per se } \\
\text { to antimicrobial peptide resistance. }\end{array}$} \\
\hline
\end{tabular}

injury? Cofactors such as intercurrent viral infection could produce a transient defect in an otherwise effective AMP barrier to invasive disease.

In summary, human medicine must contend with the fact that some bacterial pathogens have developed their own form of "innate immunity": a resistance to the AMP component of our epithelial and cellular defense. Improved knowledge of the molecular basis of these bacterial escape mechanisms may identify novel targets for antimicrobial therapy. Such drugs could act to block bacterial cell wall modifications, efflux pumps, or inactivating factors, thereby rendering the organisms sensitive to the natural innate immune defense provided by AMPs.

\section{References}

Abachin, E., Poyart, C., Pellegrini, E., Milohanic, E., Fiedler, F., Berche, P., and Trieu-Cuot, P. (2002). Formation of D-alanyl-lipoteichoic acid is required for adhesion and virulence of Listeria monocytogenes. Mol. Microbiol. 43, 1-14.

Bader, M. W., Navarre, W. W., Shiau, W., Nikaido, H., Frye, J. G., McClelland, M., Fang, F. C., and Miller, S. I. (2003). Regulation of Salmonella typhimurium virulence gene expression by cationic antimicrobial peptides. Mol. Microbiol. 50, 219-230.

Bals, R., Wang, X., Zasloff, M., and Wilson, J. M. (1998). The peptide antibiotic LL-37/hCAP-18 is expressed in epithelia of the human lung where it has broad antimicrobial activity at the airway surface. Proc. Natl. Acad. Sci. USA.95, 9541-9546.

Birchler, T., Seibl, R., Buchner, K., Loeliger, S., Seger, R., Hossle, J. P., Aguzzi, A., and Lauener, R. P. (2001). Human Toll-like receptor 2 mediates induction of the antimicrobial peptide human beta-defensin 2 in response to bacterial lipoprotein. Eur. J. Immunol. 31, 3131-3137.

Boman, H. G., Agerberth, B., and Boman, A. (1993). Mechanisms of action on Escherichia coli of cecropin
P1 and PR-39, two antibacterial peptides from pig intestine. Infect. Immun. 61, 2978-2984.

Brodsky, I. E., Ernst, R. K., Miller, S. I., and Falkow, S. (2002). mig-14 is a Salmonella gene that plays a role in bacterial resistance to antimicrobial peptides. J. Bacteriol. 184, 3203-3213.

Brodsky, I. E., Ghori, N., Falkow, S., and Monack, D. (2005). Mig-14 is an inner membrane-associated protein that promotes Salmonella typhimurium resistance to CRAMP, survival within activated macrophages and persistent infection. Mol. Microbiol. 55, 954-972.

Brogden, K. A., Kalfa, V. C., Ackermann, M. R., Palmquist, D. E., McCray, P. B., Jr., and Tack, B. F. (2001). The ovine cathelicidin SMAP29 kills ovine respiratory pathogens in vitro and in an ovine model of pulmonary infection. Antimicrob. Agents Chemother. 45, 331-334.

Buchanan, J. T., Stannard, J., Lauth, X., Westerman, M., Ostland, V., Van Olst, J., Carlberg, J., and Nizet, V. (2005). Streptococcus iniae phosphoglucomutase is a virulence factor and target for vaccine development. Infect. Immun. (in press).

Campos, M. A., Vargas, M. A., Regueiro, V., Llompart, C. M., Alberti, S., and Bengoechea, J. A. (2004). Capsule polysaccharide mediates bacterial resistance to antimicrobial peptides. Infect. Immun. 72, 7107-7114.

Cao, M., and Helmann, J. D. (2004). The Bacillus subtilis extracytoplasmic-function sigmaX factor regulates modification of the cell envelope and resistance to cationic antimicrobial peptides. J. Bacteriol. 186, 11361146.

Ceccarelli, A. V., Cole, A. M., Park, A. K., Tahk, S., Yoshioka, D., and Ganz, T. (2001). Therapeutic effect of a pig-derived peptide antibiotic on porcine wound infections. Comp. Med. 51, 75-79.

Chalekson, C. P., Neumeister, M. W., and Jaynes, J. (2002). Improvement in burn wound infection and survival with antimicrobial peptide D2A21 (Demegel). Plast. Reconstr. Surg. 109, 1338-1343.

Crouch, M. L., Becker, L. A., Bang, I. S., Tanabe, H., Ouellette, A. J., and Fang, F. C. (2005). The alternative 
sigma factor sigma is required for resistance of Salmonella enterica serovar Typhimurium to antimicrobial peptides. Mol. Microbiol. 56, 789-799.

Detweiler, C. S., Monack, D. M., Brodsky, I. E., Mathew, H., and Falkow, S. (2003). virK, somA and rcsC are important for systemic Salmonella enterica serovar Typhimurium infection and cationic peptide resistance. Mol. Microbiol. 48, 385-400.

Devine, D. A., Marsh, P. D., Percival, R. S., Rangarajan, M., and Curtis, M. A. (1999). Modulation of antibacterial peptide activity by products of Porphyromonas gingivalis and Prevotella spp. Microbiology 145 ( Pt 4), 965-971.

Di Nardo, A., Vitiello, A., and Gallo, R. L. (2003). Cutting edge: Mast cell antimicrobial activity is mediated by expression of cathelicidin antimicrobial peptide. J. Immunol. 170, 2274-2278.

Dinulos, J. G., Mentele, L., Fredericks, L. P., Dale, B. A., and Darmstadt, G. L. (2003). Keratinocyte expression of human beta defensin 2 following bacterial infection: role in cutaneous host defense. Clin. Diagn. Lab. Immunol. 10, 161-166.

Dorschner, R. A., Pestonjamasp, V. K., Tamakuwala, S., Ohtake, T., Rudisill, J., Nizet, V., Agerberth, B., Gudmundsson, G. H., and Gallo, R. L. (2001). Cutaneous injury induces the release of cathelicidin anti-microbial peptides active against group A Streptococcus. J. Invest. Dermatol. 117, 91-97.

Dunman, P. M., Murphy, E., Haney, S., Palacios, D., Tucker-Kellogg, G., Wu, S., Brown, E. L., Zagursky, R. J., Shlaes, D., and Projan, S. J. (2001). Transcription profiling-based identification of Staphylococcus aureus genes regulated by the agr and/or sarA loci. J. Bacteriol. 183, 7341-7353.

Efstratiou, A. (2000). Group A streptococci in the 1990s. J. Antimicrob. Chemother. 45 Suppl, 3-12.

Ernst, R. K., Guina, T., and Miller, S. I. (1999a). How intracellular bacteria survive: surface modifications that promote resistance to host innate immune responses. J. Infect. Dis. 179 Supp/ 2, S326-330.

Ernst, R. K., Guina, T., and Miller, S. I. (2001). Salmonella typhimurium outer membrane remodeling: role in resistance to host innate immunity. Microbes Infect. 3, 1327-1334.

Ernst, R. K., Yi, E. C., Guo, L., Lim, K. B., Burns, J. L., Hackett, M., and Miller, S. I. (1999b). Specific lipopolysaccharide found in cystic fibrosis airway Pseudomonas aeruginosa. Science 286, 1561-1565.

Frick, I. M., Akesson, P., Rasmussen, M., Schmidtchen, A., and Bjorck, L. (2003). SIC, a secreted protein of Streptococcus pyogenes that inactivates antibacterial peptides. J. Biol. Chem. 278, 16561-16566.

Gao, L. Y., Laval, F., Lawson, E. H., Groger, R. K., Woodruff, A., Morisaki, J. H., Cox, J. S., Daffe, M., and Brown, E. J. (2003). Requirement for kasB in Mycobacterium mycolic acid biosynthesis, cell wall impermeability and intracellular survival: implications for therapy. Mol. Microbiol. 49, 1547-1563.

Garcia Vescovi, E., Soncini, F. C., and Groisman, E. A. (1994). The role of the $P h o P / P h o Q$ regulon in Salmonella virulence. Res. Microbiol. 145, 473-480.

Gionchetti, P., Amadini, C., Rizzello, F., Venturi, A., Palmonari, V., Morselli, C., Romagnoli, R., and
Campieri, M. (2002). Probiotics - role in inflammatory bowel disease. Dig. Liver. Dis. 34 Suppl 2, S58-62.

Goldman, M. J., Anderson, G. M., Stolzenberg, E. D., Kari, U. P., Zasloff, M., and Wilson, J. M. (1997). Human beta-defensin-1 is a salt-sensitive antibiotic in lung that is inactivated in cystic fibrosis. Cell 88, 553-560.

Guina, T., Yi, E. C., Wang, H., Hackett, M., and Miller, S. I. (2000). A PhoP-regulated outer membrane protease of Salmonella enterica serovar typhimurium promotes resistance to alpha-helical antimicrobial peptides. J. Bacteriol. 182, 4077-4086.

Gunn, J. S. (2001). Bacterial modification of LPS and resistance to antimicrobial peptides. J. Endotoxin Res. 7, 57-62.

Gunn, J. S., Ryan, S. S., Van Velkinburgh, J. C., Ernst, R. K., and Miller, S. I. (2000). Genetic and functional analysis of a PmrA-PmrB-regulated locus necessary for lipopolysaccharide modification, antimicrobial peptide resistance, and oral virulence of Salmonella enterica serovar typhimurium. Infect. Immun. 68, 6139-6146.

Guo, L., Lim, K. B., Poduje, C. M., Daniel, M., Gunn, J. S., Hackett, M., and Miller, S. I. (1998). Lipid A acylation and bacterial resistance against vertebrate antimicrobial peptides. Cell 95, 189-198.

Gutsmann, T., Hagge, S. O., Larrick, J. W., Seydel, U., and Wiese, A. (2001). Interaction of CAP18-derived peptides with membranes made from endotoxins or phospholipids. Biophys. J. 80, 2935-2945.

Hamilton, A., Mertz, R. H., Needham, R. H. V., Lauth, X., Nizet, V., and Jones, A. L. (2004). Evasion of innate immunity: A novel function for GBS penicillin-binding protein 1a. Paper presented at: American Society for Microbiology General Meeting (New Orleans, LA).

Heilborn, J. D., Nilsson, M. F., Kratz, G., Weber, G., Sorensen, O., Borregaard, N., and Stahle-Backdahl, M. (2003). The cathelicidin anti-microbial peptide LL-37 is involved in re-epithelialization of human skin wounds and is lacking in chronic ulcer epithelium. J. Invest. Dermatol. 120, 379-389.

Hidalgo-Grass, C., Dan-Goor, M., Maly, A., Eran, Y., Kwinn, L. A., Nizet, V., Ravins, M., Jaffe, J., Peyser, A., Moses, A. E., and Hanski, E. (2004). Effect of a bacterial pheromone peptide on host chemokine degradation in group A streptococcal necrotising soft-tissue infection. Lancet 362, 696-703.

Hill, H. R., Bohnsack, J. F., Morris, E. Z., Augustine, N. H., Parker, C. J., Cleary, P. P., and Wu, J. T. (1988). Group B streptococci inhibit the chemotactic activity of the fifth component of complement. J. Immunol. 141, 3551-3556.

Hooper, L. V., Stappenbeck, T. S., Hong, C. V., and Gordon, J. I. (2003). Angiogenins: a new class of microbicidal proteins involved in innate immunity. Nat. Immunol. 4, 269-273.

limura, M., Gallo, R. L., Hase, K., Miyamoto, Y., Eckmann, L., and Kagnoff, M. F. (2005). Cathelicidin mediates innate intestinal defense against colonization with epithelial adherent bacterial pathogens. J. Immunol. 174, 4901-4907.

Islam, D., Bandholtz, L., Nilsson, J., Wigzell, H., Christensson, B., Agerberth, B., and Gudmundsson, G. (2001). Downregulation of bactericidal peptides in 
enteric infections: a novel immune escape mechanism with bacterial DNA as a potential regulator. Nat. Med. 7, 180-185.

Jerse, A. E., Sharma, N. D., Simms, A. N., Crow, E. T., Snyder, L. A., and Shafer, W. M. (2003). A gonococcal efflux pump system enhances bacterial survival in a female mouse model of genital tract infection. Infect. Immun. 71, 5576-5582.

Jin, T., Bokarewa, M., Foster, T., Mitchell, J., Higgins, J., and Tarkowski, A. (2004). Staphylococcus aureus resists human defensins by production of staphylokinase, a novel bacterial evasion mechanism. J. Immunol. 172, 1169-1176.

Kobayashi, K. S., Chamaillard, M., Ogura, Y., Henegariu, O., Inohara, N., Nunez, G., and Flavell, R. A. (2005). Nod2-dependent regulation of innate and adaptive immunity in the intestinal tract. Science 307, 731-734.

Kristian, S. A., Durr, M., Van Strijp, J. A., Neumeister, B., and Peschel, A. (2003a). MprF-mediated lysinylation of phospholipids in Staphylococcus aureus leads to protection against oxygen-independent neutrophil killing. Infect. Immun. 71, 546-549.

Kristian, S. A., Lauth, X., Nizet, V., Goetz, F., Neumeister, B., Peschel, A., and Landmann, R. (2003b). Alanylation of teichoic acids protects Staphylococcus aureus against Toll-like receptor 2-dependent host defense in a mouse tissue cage infection model. J. Infect. Dis. 188, 414-423.

Kupferwasser, L. I., Skurray, R. A., Brown, M. H., Firth, N., Yeaman, M. R., and Bayer, A. S. (1999). Plasmidmediated resistance to thrombin-induced platelet microbicidal protein in staphylococci: role of the qacA locus. Antimicrob. Agents Chemother. 43, 2395-2399.

Landers, C. J., Cohavy, O., Misra, R., Yang, H., Lin, Y. C., Braun, J., and Targan, S. R. (2002). Selected loss of tolerance evidenced by Crohn's disease-associated immune responses to auto- and microbial antigens. Gastroenterology 123, 689-699.

Lauth, X., McNamara, C. W., Myskowski, S., Igwe, E., Beall, B., Ghosh, P., Gallo, R. L., and Nizet, V. (2004). A new virulence role for group A streptococcal M1 protein is protection against cathelicidin antimicrobial peptides. Paper presented at: American Society for Microbiology General Meeting (New Orleans, LA).

Lee, P. H., Ohtake, T., Zaiou, M., Murakami, M., Rudisill, J. A., Lin, K. H., Gallo R. L. (2005) Expression of an additional cathelicidin antimicrobial peptide protects against bacterial skin infection. Proc. Natl. Acad. Sci. USA. 102, 3750-3755.

Levy, S. B. (2002). Active efflux, a common mechanism for biocide and antibiotic resistance. J. Appl. Microbiol. 92 Suppl, 65S-71S.

Liu, L., Roberts, A. A., and Ganz, T. (2003). By IL1 signaling, monocyte-derived cells dramatically enhance the epidermal antimicrobial response to lipopolysaccharide. J. Immunol. 170, 575-580.

Lopez-Solanilla, E., Gonzalez-Zorn, B., Novella, S., Vazquez-Boland, J. A., and Rodriguez-Palenzuela, P. (2003). Susceptibility of Listeria monocytogenes to antimicrobial peptides. FEMS Microbiol. Lett. 226, 101-105.
Lushbaugh, W. B., Blossom, A. C., Shah, P. H., Banga, A. K., Jaynes, J. M., Cleary, J. D., and Finley, R. W. (2000). Use of intravaginal microbicides to prevent acquisition of Trichomonas vaginalis infection in Lactobacilluspretreated, estrogenized young mice. Am. J. Trop. Med. Hyg. 63, 284-289.

Lysenko, E. S., Gould, J., Bals, R., Wilson, J. M., and Weiser, J. N. (2000). Bacterial phosphorylcholine decreases susceptibility to the antimicrobial peptide LL-37/hCAP18 expressed in the upper respiratory tract. Infect. Immun. 68, 1664-1671.

Macfarlane, E. L., Kwasnicka, A., and Hancock, R. E. (2000). Role of Pseudomonas aeruginosa PhoP-phoQ in resistance to antimicrobial cationic peptides and aminoglycosides. Microbiology 146 ( Pt 10), 25432554.

Marceau, M., Sebbane, F., Collyn, F., and Simonet, M. (2003). Function and regulation of the Salmonellalike $p m r F$ antimicrobial peptide resistance operon in Yersinia pseudotuberculosis. Adv. Exp. Med. Biol. 529, 253-256.

Mason, K. M., Munson, R. S., Jr., and Bakaletz, L. O. (2005). A mutation in the sap operon attenuates survival of nontypeable Haemophilus influenzae in a chinchilla model of otitis media. Infect. Immun. 73, 599-608.

McCoy, A. J., Liu, H., Falla, T. J., and Gunn, J. S. (2001). Identification of Proteus mirabilis mutants with increased sensitivity to antimicrobial peptides. Antimicrob. Agents Chemother. 45, 2030-2037.

McPhee, J. B., Lewenza, S., and Hancock, R. E. (2003). Cationic antimicrobial peptides activate a two-component regulatory system, PmrA-PmrB, that regulates resistance to polymyxin $B$ and cationic antimicrobial peptides in Pseudomonas aeruginosa. Mol. Microbiol. 50, 205-217.

Morrison, G., Kilanowski, F., Davidson, D., and Dorin, J. (2002). Characterization of the mouse beta defensin 1 , Defb1, mutant mouse model. Infect. Immun. 70, 30533060.

Moser, C., Weiner, D. J., Lysenko, E., Bals, R., Weiser, J. N., and Wilson, J. M. (2002). beta-Defensin 1 contributes to pulmonary innate immunity in mice. Infect. Immun. 70, 3068-3072.

Moskowitz, S. M., Ernst, R. K., and Miller, S. I. (2004). $\mathrm{PmrAB}$, a two-component regulatory system of Pseudomonas aeruginosa that modulates resistance to cationic antimicrobial peptides and addition of aminoarabinose to lipid A. J. Bacteriol. 186, 575-579.

Naser, S. A., Ghobrial, G., Romero, C., and Valentine, J. F. (2004). Culture of Mycobacterium avium subspecies paratuberculosis from the blood of patients with Crohn's disease. Lancet 364, 1039-1044.

Nishi, H., Komatsuzawa, H., Fujiwara, T., McCallum, N., and Sugai, M. (2004). Reduced content of lysylphosphatidylglycerol in the cytoplasmic membrane affects susceptibility to moenomycin, as well as vancomycin, gentamicin, and antimicrobial peptides, in Staphylococcus aureus. Antimicrob. Agents Chemother. 48, 4800-4807.

Nizet, V., Ohtake, T., Lauth, X., Trowbridge, J., Rudisill, J., Dorschner, R. A., Pestonjamasp, V., Piraino, J., Huttner, K., and Gallo, R. L. (2001). Innate antimicrobial peptide 
protects the skin from invasive bacterial infection. Nature 414, 454-457.

Ong, P. Y., Ohtake, T., Brandt, C., Strickland, I., Boguniewicz, M., Ganz, T., Gallo, R. L., and Leung, D. Y. (2002). Endogenous antimicrobial peptides and skin infections in atopic dermatitis. N. Engl. J. Med. 347, 1151-1160.

Oren, Z., Lerman, J. C., Gudmundsson, G. H., Agerberth, B., and Shai, Y. (1999). Structure and organization of the human antimicrobial peptide LL-37 in phospholipid membranes: relevance to the molecular basis for its non-cell-selective activity. Biochem. J. 341 ( Pt 3), 501513.

Park, P. W., Pier, G. B., Hinkes, M. T., and Bernfield, M. (2001). Exploitation of syndecan-1 shedding by Pseudomonas aeruginosa enhances virulence. Nature 411, 98-102.

Park, P. W., Pier, G. B., Preston, M. J., Goldberger, O., Fitzgerald, M. L., and Bernfield, M. (2000). Syndecan-1 shedding is enhanced by LasA, a secreted virulence factor of Pseudomonas aeruginosa. J. Biol. Chem. 275, 3057-3064.

Parra-Lopez, C., Lin, R., Aspedon, A., and Groisman, E. A. (1994). A Salmonella protein that is required for resistance to antimicrobial peptides and transport of potassium. EMBO. J. 13, 3964-3972.

Peschel, A. (2002). How do bacteria resist human antimicrobial peptides? Trends Microbiol 10, 179-186.

Peschel, A., and Collins, L. V. (2001). Staphylococcal resistance to antimicrobial peptides of mammalian and bacterial origin. Peptides 22, 1651-1659.

Peschel, A., Jack, R. W., Otto, M., Collins, L. V., Staubitz, P., Nicholson, G., Kalbacher, H., Nieuwenhuizen, W. F., Jung, G., Tarkowski, A., et al. (2001). Staphylococcus aureus resistance to human defensins and evasion of neutrophil killing via the novel virulence factor MprF is based on modification of membrane lipids with I-lysine. J. Exp. Med. 193, 1067-1076.

Peschel, A., Otto, M., Jack, R. W., Kalbacher, H., Jung, G., and Gotz, F. (1999). Inactivation of the dlt operon in Staphylococcus aureus confers sensitivity to defensins, protegrins, and other antimicrobial peptides. J. Biol. Chem. 274, 8405-8410.

Poyart, C., Pellegrini, E., Marceau, M., Baptista, M., Jaubert, F., Lamy, M. C., and Trieu-Cuot, P. (2003). Attenuated virulence of Streptococcus agalactiae deficient in D-alanyl-lipoteichoic acid is due to an increased susceptibility to defensins and phagocytic cells. Mol. Microbiol. 49, 1615-1625.

Putsep, K., Carlsson, G., Boman, H. G., and Andersson, M. (2002). Deficiency of antibacterial peptides in patients with morbus Kostmann: an observation study. Lancet 360, 1144-1149.

Robey, M., O'Connell, W., and Cianciotto, N. P. (2001). Identification of Legionella pneumophila rcp, a pagP-like gene that confers resistance to cationic antimicrobial peptides and promotes intracellular infection. Infect. Immun. 69, 4276-4286.

Rosenberger, C. M., Gallo, R. L., and Finlay, B. B. (2004). Interplay between antibacterial effectors: A macrophage antimicrobial peptide impairs intracellular
Salmonella replication. Proc. Natl. Acad. Sci. USA.101, 2422-2427.

Salzman, N. H., Ghosh, D., Huttner, K. M., Paterson, Y., and Bevins, C. L. (2003). Protection against enteric salmonellosis in transgenic mice expressing a human intestinal defensin. Nature 42, 522-526.

Sawamura, D., Goto, M., Shibaki, A., Akiyama, M., McMillan, J. R., Abiko, Y., and Shimizu, H. (2005). Beta defensin-3 engineered epidermis shows highly protective effect for bacterial infection. Gene. Ther. 12, 857-861.

Schmidtchen, A., Frick, I. M., Andersson, E., Tapper, H., and Bjorck, L. (2002). Proteinases of common pathogenic bacteria degrade and inactivate the antibacterial peptide LL-37. Mol. Microbiol. 46, 157168.

Schmidtchen, A., Frick, I. M., and Bjorck, L. (2001). Dermatan sulphate is released by proteinase of common pathogenic bacteria and inactivates antibacterial alphadefensin. Mol. Microbiol. 39, 708-713.

Shafer, W. M., Qu, X., Waring, A. J., and Lehrer, R. I. (1998). Modulation of Neisseria gonorrhoeae susceptibility to vertebrate antibacterial peptides due to a member of the resistance/nodulation/division efflux pump family. Proc. Natl. Acad. Sci. USA. 95, 1829-1833.

Shelburne, C. E., Coulter, W. A., Olguin, D., Lantz, M. S., and Lopatin, D. E. (2005). Induction of $\beta$-defensin resistance in the oral anaerobe Porphyromonas gingivalis. Antimicrob. Agents Chemother. 49, 183187.

Shinnar, A. E., Butler, K. L., and Park, H. J. (2003). Cathelicidin family of antimicrobial peptides: proteolytic processing and protease resistance. Bioorg. Chem. 31, 425-436.

Sieprawska-Lupa, M., Mydel, P., Krawczyk, K., Wojcik, K., Puklo, M., Lupa, B., Suder, P., Silberring, J., Reed, M., Pohl, J., et al. (2004). Degradation of human antimicrobial peptide LL-37 by Staphylococcus aureusderived proteinases. Antimicrob. Agents Chemother. 48, 4673-4679.

Smith, J. J., Travis, S. M., Greenberg, E. P., and Welsh, M. J. (1996). Cystic fibrosis airway epithelia fail to kill bacteria because of abnormal airway surface fluid. Cell 85, 229-236.

Starner, T. D., Swords, W. E., Apicella, M. A., and McCray, P. B., Jr. (2002). Susceptibility of nontypeable Haemophilus influenzae to human beta-defensins is influenced by lipooligosaccharide acylation. Infect. Immun. 70, 5287-5289.

Staubitz, P., Neumann, H., Schneider, T., Wiedemann, I., and Peschel, A. (2004). MprF-mediated biosynthesis of lysylphosphatidylglycerol, an important determinant in staphylococcal defensin resistance. FEMS Microbiol. Lett. 231, 67-71.

Taggart, C. C., Greene, C. M., Smith, S. G., Levine, R. L., McCray, P. B., Jr., O'Neill, S., and McElvaney, N. G. (2003). Inactivation of human beta-defensins 2 and 3 by elastolytic cathepsins. J. Immunol. 171, 931-937.

Tomasinsig, L., Scocchi, M., Di Loreto, C., Artico, D., and Zanetti, M. (2002). Inducible expression of an antimicrobial peptide of the innate immunity in 
polymorphonuclear leukocytes. J. Leukoc. Biol. 72, 1003-1010.

Ulvatne, H., Haukland, H. H., Samuelsen, O., Kramer, M., and Vorland, L. H. (2002). Proteases in Escherichia coli and Staphylococcus aureus confer reduced susceptibility to lactoferricin B. J.Antimicrob. Chemother. 50, 461-467.

Veal, W. L., Nicholas, R. A., and Shafer, W. M. (2002). Overexpression of the MtrC-MtrD-MtrE efflux pump due to an $m t r R$ mutation is required for chromosomally mediated penicillin resistance in Neisseria gonorrhoeae. J. Bacteriol. 184, 5619-5624.

Wang, X., Zhang, Z., Louboutin, J. P., Moser, C., Weiner, D. J., and Wilson, J. M. (2003). Airway epithelia regulate expression of human beta-defensin 2 through Toll-like receptor 2. FASEB. J. 17, 1727-1729.

Wehkamp, J., Schmid, M., Fellermann, K., and Stange, E. F. (2005). Defensin deficiency, intestinal microbes, and the clinical phenotypes of Crohn's disease. J. Leukoc. Biol. 77, 460-465.

Weiser, J. N., Bae, D., Fasching, C., Scamurra, R. W., Ratner, A. J., and Janoff, E. N. (2003). Antibody- enhanced pneumococcal adherence requires $\lg A 1$ protease. Proc. Natl. Acad. Sci. USA. 100, 4215-4220.

West, N. P., Jungnitz, H., Fitter, J. T., McArthur, J. D., Guzman, C. A., and Walker, M. J. (2000). Role of phosphoglucomutase of Bordetella bronchiseptica in lipopolysaccharide biosynthesis and virulence. Infect. Immun. 68, 4673-4680.

Wilson, C. L., Ouellette, A. J., Satchell, D. P., Ayabe, T., Lopez-Boado, Y. S., Stratman, J. L., Hultgren, S. J., Matrisian, L. M., and Parks, W. C. (1999). Regulation of intestinal alpha-defensin activation by the metalloproteinase matrilysin in innate host defense. Science 286, 113-117.

Wu, H., Zhang, G., Minton, J. E., Ross, C. R., and Blecha, F. (2000). Regulation of cathelicidin gene expression: induction by lipopolysaccharide, interleukin-6, retinoic acid, and Salmonella enterica serovar typhimurium infection. Infect. Immun. 68, 5552-5558.

Zgurskaya, H. I. (2002). Molecular analysis of efflux pumpbased antibiotic resistance. Int. J. Med. Microbiol. 292, 95-105. 


\section{Further Reading}

Caister Academic Press is a leading academic publisher of advanced texts in microbiology, molecular biology and medical research. Full details of all our publications at caister.com

- MALDI-TOF Mass Spectrometry in Microbiology Edited by: M Kostrzewa, S Schubert (2016) www.caister.com/malditof

- Aspergillus and Penicillium in the Post-genomic Era Edited by: RP Vries, IB Gelber, MR Andersen (2016) www.caister.com/aspergillus2

- The Bacteriocins: Current Knowledge and Future Prospects Edited by: RL Dorit, SM Roy, MA Riley (2016)

www.caister.com/bacteriocins

- Omics in Plant Disease Resistance Edited by: V Bhadauria (2016) www.caister.com/opd

- Acidophiles: Life in Extremely Acidic Environments Edited by: R Quatrini, DB Johnson (2016) www.caister.com/acidophiles

- Climate Change and Microbial Ecology: Current Research and Future Trend

Edited by: J Marxsen (2016)

www.caister.com/climate

- Biofilms in Bioremediation: Current Research and Emerging Technologies

Edited by: G Lear (2016)

www.caister.com/biorem

- Microalgae: Current Research and Applications Edited by: MN Tsaloglou (2016) www.caister.com/microalgae

- Gas Plasma Sterilization in Microbiology: Theory, Applications, Pitfalls and New Perspectives Edited by: H Shintani, A Sakudo (2016) www.caister.com/gasplasma

- Virus Evolution: Current Research and Future Directions Edited by: SC Weaver, M Denison, M Roossinck, et al. (2016) www.caister.com/virusevol

- Arboviruses: Molecular Biology, Evolution and Control Edited by: N Vasilakis, DJ Gubler (2016) www.caister.com/arbo

- Shigella: Molecular and Cellular Biology Edited by: WD Picking, WL Picking (2016) www.caister.com/shigella

-Aquatic Biofilms: Ecology, Water Quality and Wastewater Treatment

Edited by: AM Romaní, H Guasch, MD Balaguer (2016)

www.caister.com/aquaticbiofilms

- Alphaviruses: Current Biology

Edited by: S Mahalingam, L Herrero, B Herring (2016)

www.caister.com/alpha

- Thermophilic Microorganisms

Edited by: F Li (2015)

www.caister.com/thermophile
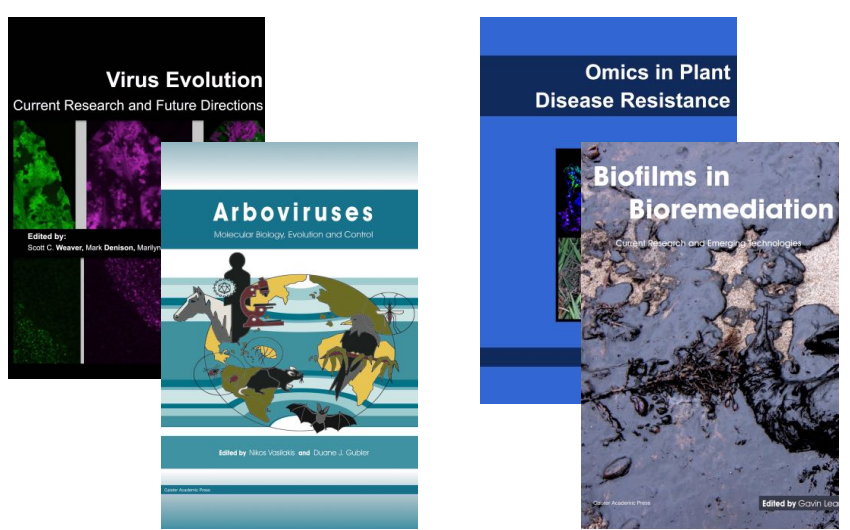
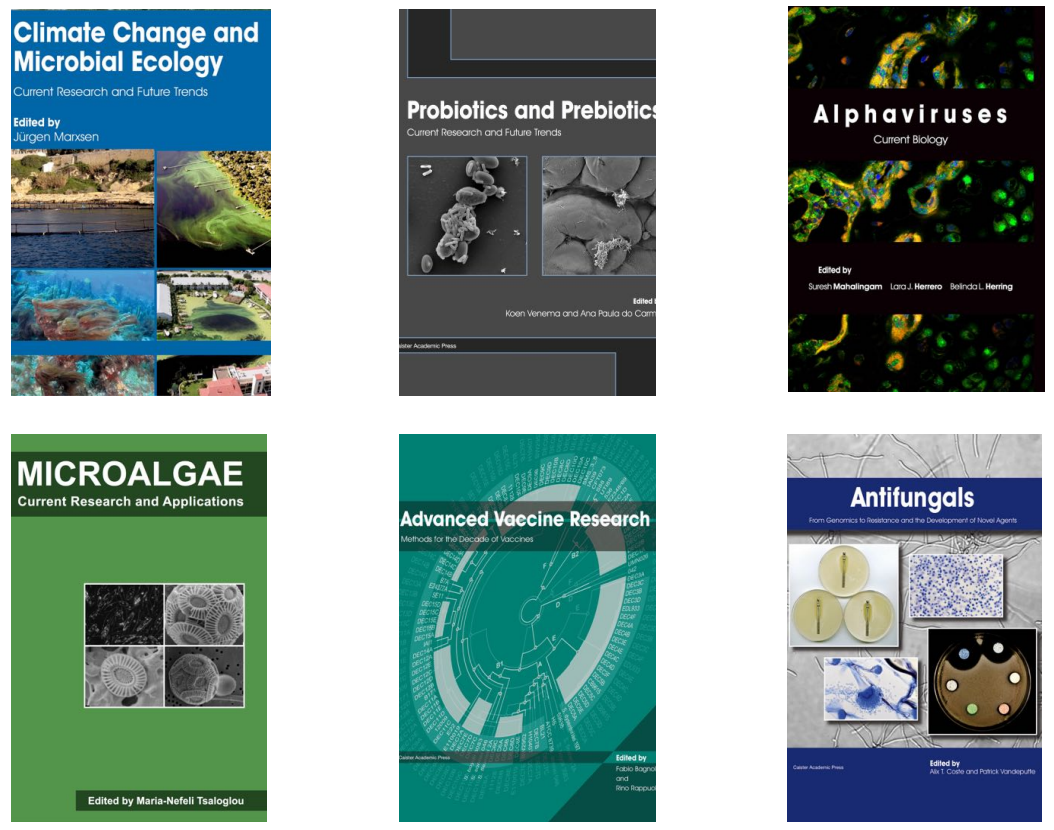

- Flow Cytometry in Microbiology: Technology and Applications Edited by: MG Wilkinson (2015) www.caister.com/flow

- Probiotics and Prebiotics: Current Research and Future Trends Edited by: K Venema, AP Carmo (2015) www.caister.com/probiotics

- Epigenetics: Current Research and Emerging Trends Edited by: BP Chadwick (2015) www.caister.com/epigenetics2015

- Corynebacterium glutamicum: From Systems Biology to Biotechnological Applications

Edited by: A Burkovski (2015)

www.caister.com/cory2

- Advanced Vaccine Research Methods for the Decade of Vaccines

Edited by: F Bagnoli, R Rappuoli (2015)

www.caister.com/vaccines

- Antifungals: From Genomics to Resistance and the Development of Novel Agents

Edited by: AT Coste, P Vandeputte (2015)

www.caister.com/antifungals

- Bacteria-Plant Interactions: Advanced Research and Future Trends Edited by: J Murillo, BA Vinatzer, RW Jackson, et al. (2015) www.caister.com/bacteria-plant

\section{- Aeromonas}

Edited by: J Graf (2015)

www.caister.com/aeromonas

- Antibiotics: Current Innovations and Future Trends

Edited by: S Sánchez, AL Demain (2015)

www.caister.com/antibiotics

- Leishmania: Current Biology and Contro Edited by: S Adak, R Datta (2015) www.caister.com/leish2

- Acanthamoeba: Biology and Pathogenesis (2nd edition) Author: NA Khan (2015)

www.caister.com/acanthamoeba2

- Microarrays: Current Technology, Innovations and Applications Edited by: Z He (2014)

www.caister.com/microarrays2

- Metagenomics of the Microbial Nitrogen Cycle: Theory, Methods and Applications

Edited by: D Marco (2014)

www.caister.com/n2 